subjects, but they did not attempt to relate this change to the presence of vascular disease. In the present series there was no tendency for immunoreactive insulin to disappear from the circulation more slowly in those patients with obvious vascular disease, though the mean time of disappearance was slower than that in non-diabetic subjects, a finding which supports the previous report by Stimmler (1967). This would suggest that there was no barrier to the passage of insulin out of the circulation owing to vascular disease, but it cannot be regarded as being conclusive because of the importance of hepatic removal of insulin in determining the acute disappearance from the circulation (Kaplan and Madison, 1959). On the other hand, there is some evidence that insulin insensitivity may precede vascular change, as 12 out of 25 diabetic patients studied within a month of diagnosis showed evidence of insulin insensitivity with a glucose assimilation index of less than 1.5 .

The possibility that there is a circulating insulin antagonist, either in plasma or at a tissue level, has been debated since the division of diabetics into so-called insulin-sensitive and insensitive types by Himsworth (1936). The recent finding that a peptide fragment of growth hormone has an inhibitory effect on insulin-like activity at the glyceraldehyde dehydrogenase step (Bornstein, Krahl, Marshall, Gould, and Armstrong, 1968) is of great interest. It seems possible that an excess of such an inhibitor could provide an explanation of the early occurrence of insulin insensitivity in recently diagnosed diabetics. So far, however, this activity has been demonstrated only in extracted pituitary tissue, and has not been convincingly shown to occur in plasma or to be related to insulin insensitivity.

A possible sequence of events suggested by the above findings is that insensitivity to insulin present from the outset of diabetes may allow hyperglycaemia (and thus poor control) and cause glucose metabolism to be directed along non-insulin-dependent pathways, giving rise among other things to an increased production of glucosamine and mucopolysaccharides (Spiro, 1963). These could be important in accelerating the development of diabetic vascular disease.
A prospective study to determine the time relationship between insulin insensitivity and vascular disease is in progress. If this supports the above hypothesis the insulin sensitivity test could be used early in the course of diabetes to help define a group of patients at greater risk of developing atherosclerosis and microangiopathy.

We are grateful to Dr. W. G. Oakley, Physician in Charge, Diabetic Department, King's College Hospital, London, for permission to study patients under his care. The help of Dr. I. McDonald, Department of Biochemistry, Guy's Hospital, and Dr. C. W. Baird and Miss Margaret Pearson, of the Department of Biochemistry, Royal Melbourne Hospital, are acknowledged.

This study was supported by a Sheppard M. Lowe Scholarship of the University of Melbourne (A. E. S.) and by the National Health and Medical Research Council of Australia.

\section{REFERENCES}

Bornstein, J., Krahl, M. E., Marshall, L. B., Gould, M. K., and Armstrong, J. (1968). Biochimica et Biophysica Acta, 156, 31 . Butterfield, W. J. H., Garratt, C. J., and Whichelow, M. J. (1963). Clinical Science, 24, 331.

Fullerton, M., and Martin, F. I. R. (1968). Medical fournal of Australia, 2, 744 .

Himsworth, H. (1936). Lancet, 1, 127.

Joslin, E. P. (1946). New England fournal of Medicine, 234, 442.

Kaplan, N., and Madison, L. L. (1959). Clinical Research, 7, 145.

Lofland, H. B., jun. (1964). Analytical Biochemistry, 9, 393.

Martin, F. I. R., and Stocks, A. E. (1967). Australasian Annals of Medicine, 16, 289.

Martin, F. I. R., and Stocks, A. E. (1968). British Medical Journal, 2, 81 .

Norgaard, A., and Thaysen, T. E. (1929). Acta Medica Scandinavica, 72, 492.

Pearson, M. J., Fullerton, M. J., Martin, F. I. R., and Melick, R. (1968). Proceedings of the Australian Association of Clinical Biochemists, 1, 315 .

Snedecor, G. W. (1956). Statistical Methods, Applied to Experiments in Agriculture and Biology, 5th ed. Ames, Iowa, Iowa State College Press.

Spiro, R. G. (1963). New England fournal of Medicine, 269, 566.

Stimmler, L. (1967). Diabetes, 16, 652

Stocks, A. E., Pearson, M. J., and Odom, N. J. (1968). Guy's Hospital Reports, 117, 275 .

Wilson, J. L., Root, H. F., and Marble, A. (1951). American fournal of the Medical Sciences, 221, 479.

\title{
Mechanism of Action of $\beta$-Adrenergic Receptor Blocking Agents in Angina Pectoris : Comparison of Action of Propranolol with Dexpropranolol and Practolol
}

\author{
A. G. WILSON,* M.B., B.S., M.R.C.P. ; O. G. BROOKE, $\dagger$ M.B., B.S., M.R.C.P. ; H. J. LLOYD, $†$ M.B., B.S., M.R.C.P. \\ B. F. ROBINSON, $\ddagger$ M.D., M.R.C.P.
}

British Medical fournal, 1969, 4, 399-401

\begin{abstract}
Summary : The effect on exercise tolerance of racemic $\checkmark$ propranolol has been assessed in eight angina pectoris patients and compared with that of dexpropranolol (the dextro isomer of propranolol), practolol (I.C.I. 50172), and saline. Dexpropranolol has the same local anaesthetic action as propranolol with negligible $\beta$-adrenergic receptor blocking activity, while practolol is a cardio-selective $\beta$-adrenergic blocking agent which does not have local anaesthetic activity.
\end{abstract}

Saline and dexpropranolol had no significant effect on exercise time; racemic propranolol and practolol

* Medical Registrar.

† Senior House Officer.

$¥$ Senior Lecturer in Medicine.

Medical Unit, St. George's Hospital, London S.W.1. improved exercise tolerance in six subjects, the response to the two drugs being very similar in individual patients. It was concluded that the beneficial effect of propranolol in angina pectoris results from its action as a $\beta$-adrenergic receptor blocking agent and is not due to its local anaesthetic, or quinidine-like, activity.

\section{Introduction}

The effect of $\beta$-adrenergic receptor blocking agents in improving exercise tolerance in patients with angina pectoris has been confirmed by a number of controlled trials. Pronethalol, the first such agent to be used clinically, was shown to be effective in a multicentre double-blind trial (Alleyne et al., 1963), and similar results were subsequently reported with propranolol 
(Gillam and Prichard, 1965 ; Keelan, 1965 ; Rabkin et al., 1965 ; Grant et al., 1966 ; Hamer and Sowton, 1966 ; Wolfson et al., 1966 ; Gianelly et al., 1967 ; Battock et al., 1969). More recently, improvement in exercise tolerance has been reported following the administration of alprenolol (Björntorp, 1967) and oxyprenolol (Wilson et al., 1969). The mechanism by which these drugs produce improvement in exercise tolerance has not been fully elucidated, but it has been thought probable that their action results from the reduction of myocardial work brought about by attenuation of sympathetic stimulation of the heart. All of the $\beta$-adrenergic blocking agents that have been used clinically, however, also have local anaesthetic (or quinidine like) activity, and it has been suggested that this property is responsible, at least in part, for the beneficial effect in angina pectoris (Sandler et al., 1968 ; British Medical fournal, 1969). Direct depression of the myocardium as a result of a local anaesthetic action might conceivably improve exercise tolerance by reducing the oxygen requirements of the heart, but it is equally possible that it would have an adverse effect if it led to an increase in ventricular dimensions with a consequent rise in the metabolic needs of the myocardium.

Ir.vestigation of the mechanism of action of the $\beta$-receptor blocking agents in angina pectoris has recently been facilitated by the development of drugs in which local anaesthetic and $\beta$-receptor blocking activity are dissociated. Dexpropranolol, the dextro-isomer of propranolol, has been shown to have the same local anaesthetic action as ordinary propranolol (which is the racemic mixture), but negligible $\beta$-receptor blocking activity (Barrett and Cullum, 1968). Practolol (I.C.I. 50172), on the other hand, has a cardioselective $\beta$-receptor blocking action but no local anaesthetic activity (Dunlop and Shanks, 1968). We have used these drugs to investigate the relative importance of $\beta$-adrenergic blockade and of local anaesthetic or quinidine-like action in the therapeutic effect of propranolol The effect of propranolol on exercise tolerance has been assessed in eight patients with angina pectoris and the response has been compared with that following the administration of dexpropranolol, practolol, and saline to the same patients.

\section{Methods}

Eight patients with typical angina pectoris were studied; they included two women and six men. Every patient had received a detailed explanation of the nature of the investigation before consenting to take part. Each patient was studied at the same time of day on each occasion, and in those who were receiving propranolol therapeutically the drug was withdrawn for at least 18 hours before each study. The patients exercised on a bicycle ergometer in the upright position and the electrocardiogram was recorded at intervals of a minute throughout each test and at the time of onset of pain. One patient was unable to operate the ergometer satisfactorily and performed a step test in time with a metronome instead.
Each patient was familiarized with the bicycle ergometer and a level of work was found that would regularly provoke pain in less than two and a half minutes. On each day of the study two control bouts of exercise were performed with about 10 minutes' rest between, and the time taken to provoke pain and the heart rate attained were recorded. An intravenous injection was then given which consisted of saline, propranolol $(0.15 \mathrm{mg} . / \mathrm{kg}$.), dexpropranolol $(0.15 \mathrm{mg} . / \mathrm{kg}$.), or practolol $(0.30 \mathrm{mg} . / \mathrm{kg}$.). Practolol was given in a dose twice that of propranolol because it was desired to achieve comparable attenuation of sympathetic stimulation of the heart with the two drugs; animal experiments have suggested that, weight for weight, practolol is less than half as active as propranolol in producing $\beta$-adrenergic receptor blockade (Dunlop and Shanks, 1968), and in the initial experiments of the present study it was confirmed that the drugs had comparable effects on exercising heart rate in man when given in the dose ratio selected. About 10 minutes after the injection two further bouts of exercise were performed and the exercise time and heart rate were again recorded.

The whole study was repeated on three further occasions and the substances not used on the first day were each given once ; in one subject, however, it was not possible to complete the study with saline. The order in which the agents were given was varied from patient to patient, and the subjects were unaware of what they were receiving on a particular occasion. The results were expressed as the averages for the paired bouts of exercise before and after each intervention. The heart rate shown in the Table was recorded at the same time in the exercise test both before and after the intervention, and it is not necessarily the rate at the time of pain. The significance of changes in the mean results for the whole group was calculated by Student's $t$ test for paired data.

\section{Results}

Exercise Tolerance.-The results are shown in the Table. The administration of saline was not followed by more than a slight change in exercise time in any patient and the average for the group was unchanged. Following propranolol, four patients showed large increases in exercise time, two showed smaller increases, and two showed small decreases; the average for the group increased by 46 seconds, but this change did not quite achieve statistical significance at the $5 \%$ level. Following dexpropranolol, the changes in exercise time were small and comparable to those following saline; the average time for the whole group increased by only one second, and this was not a significant change. Following practolol there was a large increase in exercise time in four patients, a smaller increase in one, and essentially no change in the remaining three ; the average for the group was an increase of 36 seconds, and this change was significant $(P<0.05)$. The response of individual patients to propranolol and practolol was similar-

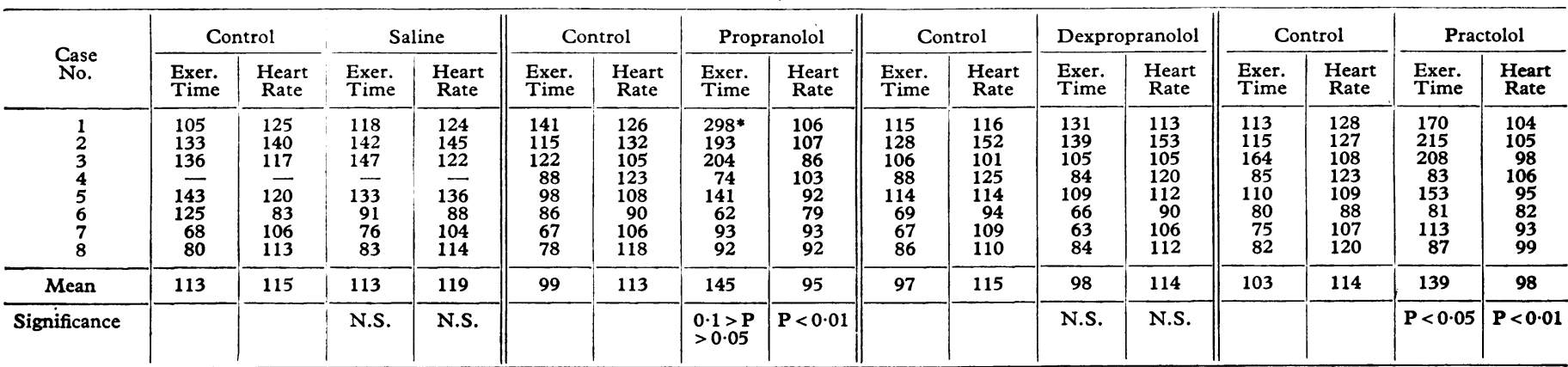

* Rate of work was increased by 20 watts after $240 \mathrm{sec}$.

Exer. time = Average time in seconds before pain developed in two tests conducted about 15 minutes apart.

Heart rate $=$ Rate per minute at the same time in the exercise test before and after the intervention; each value shows the average of paired studies. N.S. $=$ Not significant. 
the four patients who were much improved were the same with each drug, and the two who obtained no benefit from propranolol also failed to respond to practolol.

Heart Rate.-Following saline there was on average a small increase in exercising heart rate, but this was not statistically significant. Following racemic propranolol heart rate decreased by 18 beats $/ \mathrm{min}$. on average, and this change was highly significant $(\mathrm{P}<0 \cdot 01)$. Following dexpropranolol the exercising heart rate was not significantly changed. Following practolol there was a fall in exercising heart rate which amounted to 16 beats $/ \mathrm{min}$. on average, and this change was also highly significant $(\mathrm{P}<0.01)$.

\section{Discussion}

The results show that those patients with angina pectoris who respond to propranolol with an increase in exercise tolerance do not obtain similar benefit following the administration of dexpropranolol. This finding indicates that, at the dose used, the beneficial effect of propranolol is not related to its local anaesthetic or quinidine-like effect, which is possessed in full by the dextroisomer, but results from its $\beta$-adrenergic receptor blocking activity. This conclusion is reinforced by the findings with practolol, which is a cardioselective $\beta$-adrenergic receptor blocking agent with no local anaesthetic activity; when this drug was given in a dose that had an effect on exercising heart rate comparable to that observed following propranolol, the effect on exercise tolerance was very similar.

The results thus provide no evidence that the local anaesthetic action of propranolol plays any part in improving exercise tolerance in patients with angina pectoris, but neither do they show any evidence that it is harmful. The findings in the patients whose exercise tolerance failed to improve after propranolol are of particular interest in this respect. In most studies in which propranolol has been found to be effective in increasing exercise tolerance in angina pectoris there have been some patients who did not obtain any benefit. One possible explanation for this failure to respond might have been that the local anaesthetic action of the drug exerted an adverse effect which offset the beneficial effect of $\beta$-adrenergic blockade. The present investigation included two patients whose exercise tolerance deteriorated following propranolol (with the result that the change in exercise time for the group as a whole did not achieve the conventional level of significance). In neither patient, however, was there more than a minimal reduction in exercise time following dexpropranolol, and it does not appear that the local anaesthetic or quinidine-like action played any part in the failure to respond.

The conclusion that the local anaesthetic action of propranolol has no effect, either beneficial or harmful, on exercise tolerance in angina pectoris is, of course, valid only for the dose used. The amount given was, however, comparable in its effects to the doses commonly used clinically in the treatment of angina, and it seems unlikely that the local anaesthetic action of propranolol makes a significant contribution to its action at dose levels within the usual therapeutic range. This conclusion is in agreement with that reached by Björntorp (1968) following a study of the action of alprenolol, which is another $\beta$-adrenergic receptor blocking agent with local anaesthetic activity. He compared the action of the racemic drug with its dextro-isomer in a double-blind cross-over study in outpatients and concluded that the beneficial effect of the drug was due to its $\beta$-receptor blocking properties and not to its local anaesthetic effect.

The beneficial effect of practolol in angina pectoris has recently been reported by Areskog and Adolfsson (1969). In the present study, in which the effect of practolol has been compared with that of propranolol in the same subjects, there was a striking similarity in the response to the two drugs in individual patients: those who responded well to one responded well to the other, and those who obtained no benefit from one did not obtain any appreciable benefit from the other. It thus seems unlikely that practolol will prove helpful in the treatment of patients who have failed to obtain benefit from propranolol. The close similarity in the therapeutic effects of the two drugs is of interest in view of the significant differences in their pharmacology: practolol not only lacks the local anaesthetic action of propranolol but also differs in possessing appreciable intrinsic sympathomimetic activity and having a selective blocking action on the cardiac $\beta$-adrenergic receptors.

Although the absence of local anaesthetic activity in practolol does not appear to influence its ability to improve exercise tolerance in angina pectoris, it may not be irrelevant in considering its place in clinical practice. Patients with ischaemic heart disease are prone to develop arrhythmias and these may lead to sudden death. The local anaesthetic activity of propranolol might possibly be helpful in preventing this complication, and the possibility should be considered, and perhaps subjected to clinical trial, before propranolol is replaced on a wide scale by a $\beta$-adrenergic blocking agent that may not have the same antiarrhythmic effects.

We would like to thank Dr. J. D. Fitzgerald, of Imperial Chemical Industries, for making supplies of dexpropranolol and practolol available to us.

\section{REFERENCES}

Alleyne, G. A. O., et al. (1963). British Medical fournal, 2, 1226.

Areskog, N.-H., and Adolfsson, L. (1969). British Medical fournal, 2, 601.

Barrett, A. M., and Cullum, V. A. (1968). British fournal of Pharmaco$\log y, 34,43$.

Battock, D. J., Alvarez, H., and Chidsey, C. A. (1969). Circulation, 39, 157.

Björntorp, P. (1967). Acta Medica Scandinavica, 182, 285.

Björntorp, P. (1968). Acta Medica Scandinavica, 184, 259.

British Medical fournal, 1969, 2, 134.

Dunlop, D., and Shanks, R. G. (1968). British fournal of Pharmacology, 32, 201.

Gianelly, R. E., Goldman, R. H., Treister, B., and Harrison, D. C. (1967). Annals of Internal Medicine, 67, 1216.

Gillam, P. M. S., and Prichard, B. N. C. (1965). British Medical fournal, 2, 337.

Grant, R. H. E., et al. (1966). American fournal of Cardiology, 18, 361. Hamer, J., and Sowton, G. E. (1966). American fournal of Cardiology, 18, 354 .

Keelan, P. (1965). British Medical fournal, 1, 897.

Rabkin, R., Stables, D. P., Levin, N. W., and Suzman, M. M. (1965). American fournal of Cardiology, 18, 370.

Sandler, G., Clayton, G. A., and Thornicroft, S. G. (1968). British Medical F:urnal, 3, 224.

Wilson, D. F., Watson, O. F., Peel, J. S., and Turner, A. S. (1969). British Medical fournal, 2, 155.

Wolfson, S., et al. (1966). American fournal of Cardiology, 18, 345. 